\title{
New Method for the in vivo Estimation of Fluvastatin and its Application for Pharmacokinetic Studies in Rabbit
}

\author{
Deepthi Sandhala*, Srinivas Lankalapalli \\ GITAM Institute of Pharmacy, GITAM (Deemed to be University), Rushikonda, Visakhapatnam, Andhra Pradesh, INDIA.
}

\begin{abstract}
Aim: The study was aimed to conduct a pharmacokinetic evaluation of Fluvastatin in rabbit plasma using a sensitive HPLC method. Materials and Methods: The plasma samples were assayed by Waters alliance e-2695 HPLC instrument using symmetry $\mathrm{C}_{18}$ column $(150 \times 4.6 \mathrm{~mm}, 3.5 \mu)$ under isocratic condition. Here the buffer was $0.1 \%$ ortho phosphoric acid. Mobile phase used was acetonitrile and $0.1 \%$ ortho phosphoric acid in 50:50 v/v with a flow rate of $1 \mathrm{ml} / \mathrm{min}$. The eluent was monitored at $224 \mathrm{~nm}$ for measurement of Fluvastatin. Results: The calibration curve was linear over the concentration range of $5-200 \mathrm{ng} / \mathrm{ml}$ of Fuvastatin. Conclusion: The application denotes all the parameters of system suitability, specificity, linearity and accuracy are in good agreement with USFDA guidelines and applied effectively for the investigation of pharmacokinetic studies in rabbit.
\end{abstract}

Key words: RP-HPLC, Fluvastatin, Rabbit Plasma, Linearity, Accuracy, Pharmacokinetics.

\section{INTRODUCTION}

Fluvastatin is a member of the statin drug class, ${ }^{1-3}$ used to treat hypercholesterolemia ${ }^{4-6}$ and to prevent cardiovascular disease. Fluvastatin is an antilipemic agent that competitively inhibits hydroxymethylgultaryl-CoenzymeA reeducates. It is fully synthetic HMGCoA reeducates inhibitor. Some adverse events such as elevation in transaminase levels, headache, dyspepsia, nausea, ${ }^{7-9}$ Indigestion, ${ }^{10-12}$ Insomnia, ${ }^{13,14}$ Myalgia ${ }^{15}$ and infrequently rhabdomyolysis. ${ }^{16,17}$ Fluvastatin belongs to BCS Class II drug (High permeability and low solubility). Fluvastatin has a short biological life of 1.5-2 hr and molecular formula $\mathrm{C}_{24} \mathrm{H}_{26} \mathrm{FNO}_{4}$. The Chemical structure of Fluvastatin given in Figure 1. Fluconazole, a potent inhibitor of CYP2C9 increase Fluvastatin levels. In the present study was planned with an objective to conduct in vivo pharmacokinetic studies in rabbit. Experimental Fluvastatin sustained release tablet formulation were tried to compare with commercial Fluvastatin extended release tablets. But very few methods of Fluvastatin were reported for in vivo estimation in plasma. Hence, for the estimation of Fluvastatin in rabbit plasma it was proposed to develop a new HPLC method.

In Literature ${ }^{18-27}$ revealed many HPLC methods and UV methods for the estimation of fluvastatin. But there is no literature report of bio analytical study of fluvastatin in rabbit plasma.

\section{MATERIALS AND METHODS}

Fluvastatin (99.9\% pure) was obtained as gift sample from M/s. Aurobindo Pharma Ltd., Hyderabad, India. Commercial tablet of Fluvastatin (Lescol XL) as extended release was bought from local market.

\section{Materials}

Submission Date: 07-05-2020; Revision Date: 10-07-2020; Accepted Date: 23-10-2020

DOI: 10.5530/ijper.54.4.211 Correspondence: Miss. Deepthi Sandhala GITAM Institute of Pharmacy, GITAM (Deemed to be University), Rushikonda, Visakhapatnam-530045, Andhra Pradesh, INDIA. Phone no: +91 849-79 71337 Email id: deepthi.sandela@ gmail.com

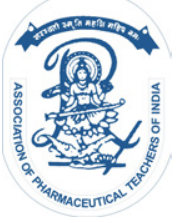

www.ijper.org 


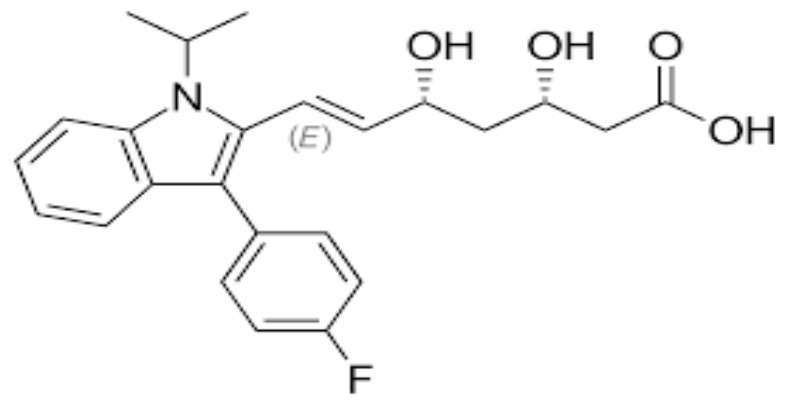

Figure 1: Structural representation of Fluvastatin.

HPLC marked acetonitrile, ortho phosphoric acid were procured from Merck, Mumbai, India. HPLC marked water was obtained from Milli Q (Milli Q system, USA) water purification.

\section{Pharmacokinetic Study}

\section{Selection of animals}

In vivo pharmacokinetic studies, 6 healthy New Zealand white rabbits (2.0-2.5 kg) were used. All animal experiments approved and performed in GITAM Institute of Pharmacy, Visakhapatnam accord with principles of Institutional Animal Ethics Committee (CPCSEA No: 1287/ac/09/CPCSEA) vide approval IAEC/GIP-1287/LS-F/Approved/1/2019.

\section{In vivo Study Design}

The animals are separated into four groups. Before experimentation all animals starved overnight and had water ad-libitum. Topical anesthetic procedure was used. Pharmacokinetic evaluation was performed for Fluvastatin solid dispersion tablets (Optimized and Marketed) optimized 20mg and $80 \mathrm{mg}$, marketed $20 \mathrm{mg}$ and $80 \mathrm{mg}$. In six different rabbits the dose was administered orally, under fasting condition. Blood samples were collected from rabbit ear vein with volume of $0.2 \mathrm{ml}$ to $0.4 \mathrm{ml}$ at $0.5,1,2,3,6,9,12,18,20$ and $24 \mathrm{hr}$. Each sample was separated by centrifugation and stored at $-70^{\circ} \mathrm{C}$ for $20 \mathrm{~min}$ with $4000 \mathrm{rpm}$.

\section{Analytical method and Instrumentation}

In this method, chromatographic condition of HPLC (Waters Alliance e2695) were $\mathrm{C}_{18}$ symmetry column $(3.5 \mu \mathrm{m}, 150 \mathrm{~mm} \times 4.6 \mathrm{~mm})$ with mobile phase of acetonitrile: $0.1 \%$ Ortho phosphoric acid $(50: 50 \mathrm{v} / \mathrm{v})$ at $1.0 \mathrm{ml} / \mathrm{min}$ flow rate under constant temperature of $30^{\circ} \mathrm{C}$ and detection was done at 224 $\mathrm{nm}$ wavelength.

\section{Preparation of Stock Solutions}

$400 \mathrm{ng} / \mathrm{ml}$ of stock solution was made with acetonitrile (5 $\mathrm{mg}$ in $25 \mathrm{ml}$ ). $40 \mu \mathrm{g} / \mathrm{ml}$ intermediate stock was made with mobile phase from stock. From stock solution, 5, $10,25,50,75,100,125,150$ and $200 \mathrm{ng} / \mathrm{ml}$ working solutions were made which were used for standard calibration curve. Similarly, $100 \mathrm{ng} / \mathrm{ml}$ atorvastatin solution of internal standard (IS) was made.

\section{Sample Preparation}

For sample preparation $200 \mu \mathrm{l}$ of plasma was taken and $500 \mu \mathrm{l}$ of internal standard and $500 \mu \mathrm{l}$ of stock solution was added and mixed. To this mixture a $500 \mu \mathrm{l}$ of acetonitrile was added to precipitate all the proteins and blend within the vortex cycle mixture. This samples further subjected for Centrifuge at $500 \mathrm{rpm}$ for $30 \mathrm{~min}$. Collect the supernatant solution and filter through $0.2 \mu \mathrm{g}$ filter and the clear solution was placed in HPLC vial for injection into the chromatogram.

\section{Method validation Specificity}

Six rabbit blank plasma samples were collected randomly and they were subjected for protein precipitation. They were chromatographed to identify the endogenous components of plasma which could interfere with either standard drug or internal standard.

\section{System suitability}

The system was assured by determining peak retention time, peak area, tailing and plate count of Fluvastatin.

\section{Linearity}

Calibration samples of different concentration (5\%, $10 \%, 25 \%, 50 \%, 75 \%, 100 \%, 125 \%, 150 \%$ and $200 \%$ ) of Fluvastatin were prepared by appropriate amount and dilution of standard drug into control plasma. The samples were further subjected for protein precipitation and chromatographed.

\section{Accuracy}

The accuracy of an analytical method describes mean test results obtained by the nominal value (concentration) of the analyte. Accuracy can be measured by using a minimum of 3 concentrations and 5 determinations per concentration. The deviation of the mean from the nominal value (relative error) serves as the measure of accuracy.

\section{Precision}

The precision of an analytical method describes the individual measures of an analyte. Precision can be measured by using a minimum of 3 concentrations and 5 determinations per concentration. Precision is 
subdivided into - Within-day precision and - Betweenday precision.

\section{Limit of detection and qualification}

The Limit of Detection (LOD) is defined as the lowest detectable concentration. Limit of Qualification (LOQ) is defined as lowest quantifiable concentration LOD and LOQ were calculated as $3.3 \sigma / \mathrm{s}$ and $10 \sigma / \mathrm{s}$ respectively. Where ' $\sigma$ ' is standard deviation (SD) of intercept and ' $s$ ' is slope of calibration curve.

\section{RESULTS AND DISCUSSION Method Validation \\ Specificity}

No interfering peaks were found in blank plasma sample at the retention time of both Fluvastatin and ISTD. The Chromatogram blank rabbit plasma was shown in Figure 2 and Chromatogram blank plasma spiked with analyte and IS shown in Figure 3.

\section{Standard calibration curve and Linearity}

From the calibration curve, it had been clear that the height area ratios were proportional to the concentration. The concentration range of Fluvastatin is $5-200 \mathrm{ng} / \mathrm{ml}$. The calibration curve was appeared linear and coefficient of correlation was found to be 0.999 . The regression coefficient value is $y=0.0075 x+0.0051$. The Linearity results of Fluvastatin are given in Table 1 and Figure 4.

\section{Precision}

In precision the Quality control sample (MQC), concentration taken was $100(\mathrm{ng} / \mathrm{ml})$. Precision was determined by $\%$ RSD. Intra and inter batch $\%$ precision

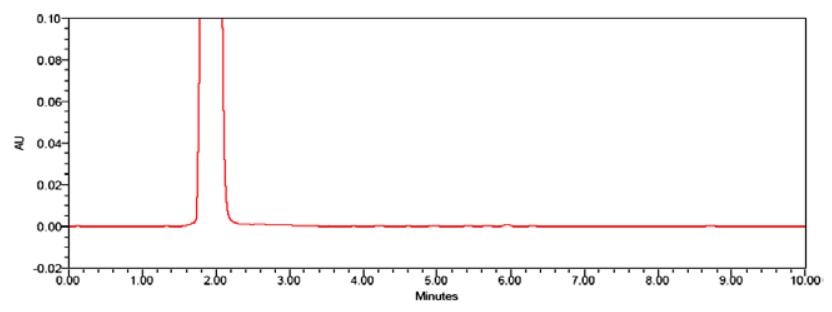

Figure 2: Chromatogram blank rabbit plasma.

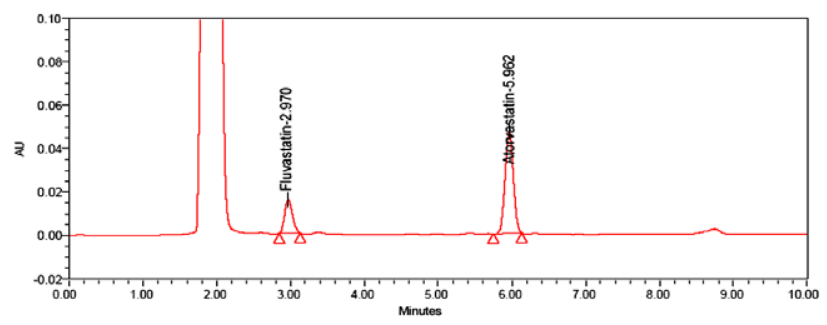

Figure 3: Chromatogram blank plasma spiked with analyte and IS.

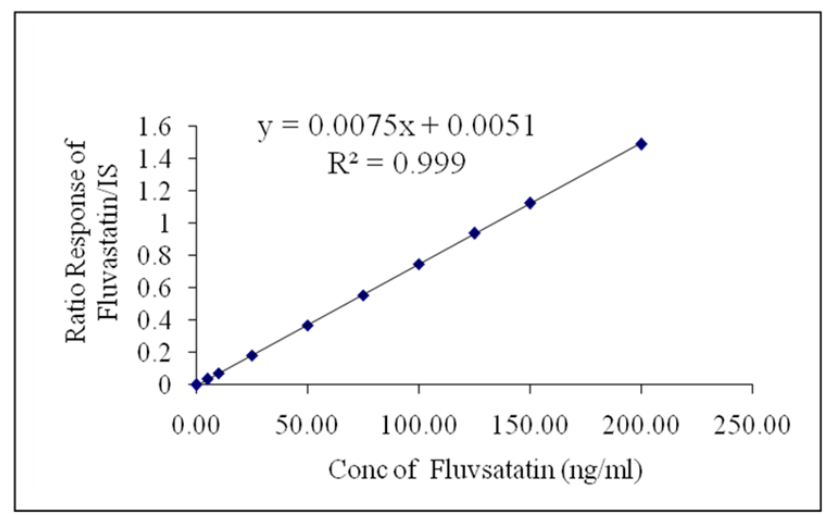

Figure 4: Linearity plot for Fluvastatin

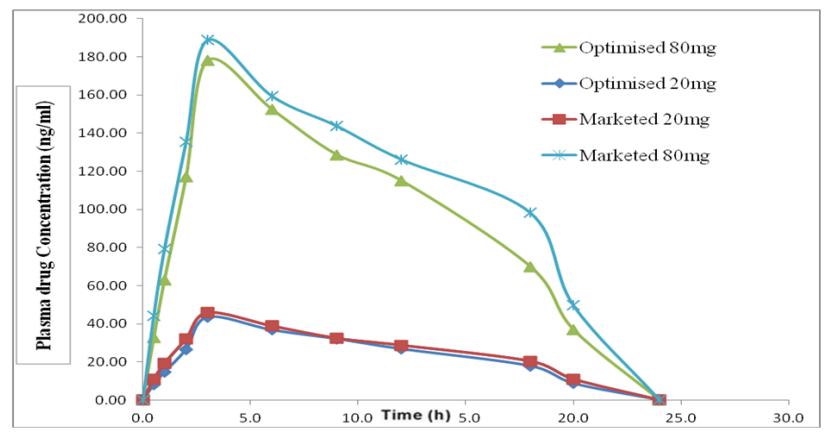

Figure 5: In vivo plasma profiles of Fluvastatin in rabbits.

for Fluvastatin was found to be 100.02 and 99.96 and $\%$ RSD varies from 0.89 and 1.27. The $\% \mathrm{CV}$ and precision results were found to be within the suitable limits.

\section{Accuracy}

In Accuracy the Quality control sample (LLQC, LQC, HQC), concentration taken was 5, 50, 200 ( $\mathrm{ng} / \mathrm{ml}$ ). Accuracy was determined by \%RSD. Intra and inter batch \% accuracy for Fluvastatin varies from 95.58100.35 and $96.12-100.82$ and \%RSD varies form 0.64 1.56 and $0.42-1.27$, The $\% \mathrm{CV}$ and accuracy results were found to be within the suitable limits.

\section{Limit of detection and qualification}

The limit of detection (LOD) and Limit of Quantification (LOQ) was estimated from the signal to noise ratio. This limit was defined as the lowest concentration level that provided a peak area with signal to noise ratio higher than 3:1 for detection and 10:1 for qualification. The LOD value was found to be $0.5 \mathrm{ng} /$ $\mathrm{ml}$ and LOQ values is $5 \mathrm{ng} / \mathrm{ml}$.

\section{Pharmacokinetic Study}

Pharmacokinetic studies of Fluvastatin in plasma samples, for calculating the pharmacological parameters with dose of $0.5 \mathrm{mg} / 1.0 \mathrm{~kg}$ of body mass (equivalent to $20 \mathrm{mg}$ of tablet) and $2.0 \mathrm{mg} / 1.0 \mathrm{~kg}$ of body mass 
Table 1: Linearity results of Fluvastatin.

\begin{tabular}{|c|c|c|c|c|}
\hline Linearity & $\begin{array}{c}\text { Fluvastatin concentration }(\mathbf{n g} / \\
\mathbf{m} \mathbf{)}\end{array}$ & $\begin{array}{c}\text { Fluvastatin peak } \\
\text { response }\end{array}$ & IS peak response & Ratio Response \\
\hline 1 & 5 & 2548 & 68542 & 0.037 \\
\hline 2 & 10 & 5115 & 68598 & 0.075 \\
\hline 3 & 25 & 12578 & 68745 & 0.183 \\
\hline 4 & 50 & 25575 & 68985 & 0.371 \\
\hline 5 & 75 & 37895 & 68154 & 0.556 \\
\hline 6 & 100 & 51154 & 68240 & 0.750 \\
\hline 7 & 125 & 63987 & 68226 & 0.938 \\
\hline 8 & 150 & 76985 & 68357 & 1.126 \\
\hline 9 & 200 & 102874 & 68974 & 1.491 \\
\hline \multicolumn{2}{c|}{ Slope } & & 0.075 \\
\hline
\end{tabular}

\begin{tabular}{|c|c|c|c|c|}
\hline \multicolumn{7}{|c|}{ Table 2: Pharmacokinetic parameters of Fluvastatin. } \\
\hline Time (hrs) & Optimized 20 mg & Marketed 20mg & Optimized 80mg & Marketed 80mg \\
\hline 0.0 & 0.00 & 0.00 & 0.00 & 0.00 \\
\hline 0.5 & 8.24 & 10.81 & 32.64 & 44.09 \\
\hline 1.0 & 14.73 & 19.23 & 63.02 & 79.29 \\
\hline 2.0 & 26.67 & 32.12 & 116.93 & 135.30 \\
\hline 3.0 & 43.63 & 45.85 & 177.95 & 188.69 \\
\hline 6.0 & 36.83 & 38.88 & 152.36 & 159.32 \\
\hline 9.0 & 32.19 & 32.44 & 128.63 & 143.72 \\
\hline 12.0 & 26.90 & 28.75 & 115.06 & 126.17 \\
\hline 18.0 & 17.92 & 20.35 & 69.99 & 98.16 \\
\hline 20.0 & 8.75 & 10.98 & 37.05 & 49.65 \\
\hline 24.0 & 0.00 & 0.00 & 0.00 & 0.00 \\
\hline
\end{tabular}

Table 3: In vivo Plasma Profiles of Fluvastatin in Rabbits.

\begin{tabular}{|c|c|c|c|c|}
\hline Pharmacokinetic parameter & Optimized 20mg & Marketed 20mg & Optimized 80mg & Marketed 80mg \\
\hline $\mathrm{AUC}_{0-\mathrm{t}(\mathrm{ng} \mathrm{h} / \mathrm{ml})}$ & 556 & 601 & 2288 & 2613 \\
\hline $\mathrm{C}_{\max }$ & 43.6 & 45.85 & 178 & 188.7 \\
\hline $\mathrm{AUC}_{0-\infty(\mathrm{ng} \mathrm{h} / \mathrm{ml})}$ & 596.5 & 707.5 & 2647 & 3094 \\
\hline $\mathrm{AUC}_{\mathrm{t}-\infty(\mathrm{ng} \mathrm{h} / \mathrm{ml})}$ & 85 & 106 & 359 & 482 \\
\hline $\mathrm{t}_{1 / 2}$ & 3 & 3 & 3 & 3 \\
\hline $\mathrm{T}_{\max }(\mathrm{h})$ & 3 & 3 & 3 & 3 \\
\hline
\end{tabular}

(equivalent to $80 \mathrm{mg}$ of tablet) for both optimized and marketed formulations. Samplings of Fluvastatin in rabbits were taken as follows, optimized $20 \mathrm{mg}, 80 \mathrm{mg}$ and marketed $20 \mathrm{mg}, 80 \mathrm{mg}$. All the formulations in rabbit are given through oral route. The pharmacokinetic profile of Fluvastatin was depicted in Figure 5 and calculated concentrations were between linearity ranges are given in Table 2.

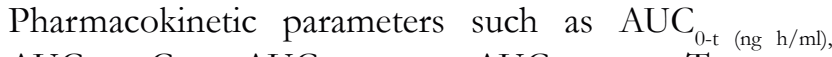
$\mathrm{AUC}_{0-\infty}, \mathrm{C}_{\max }, \quad \mathrm{AUC}_{0-\infty(\mathrm{ng} \mathrm{h} / \mathrm{ml}),} \quad \mathrm{AUC}_{\mathrm{t}-\infty(\mathrm{ng} \mathrm{h} / \mathrm{ml})} \mathrm{T}_{\max ,}$, were calculated and the data was shown in Table 3. The $\mathrm{AUC}_{0-\mathrm{t}}$ for optimized $20 \mathrm{mg}$ and $80 \mathrm{mg}$ and was found to be (556 ng h/ml, $2288 \mathrm{ng} \mathrm{h} / \mathrm{ml}$ ), marketed $20 \mathrm{mg}$ and $80 \mathrm{mg}(601 \mathrm{ng} \mathrm{h} / \mathrm{ml}, 2613 \mathrm{ng} \mathrm{h} / \mathrm{ml})$. The $\mathrm{C}_{\max }$ of optimized $20 \mathrm{mg}$ and $80 \mathrm{mg}$ was found to be $(43.6 \mathrm{ng} /$ $\mathrm{ml}, 178 \mathrm{ng} / \mathrm{ml}$ ), marketed 20mg and 80mg (45.8 ng/ $\mathrm{ml}$ and $188.7 \mathrm{ng} / \mathrm{ml}$ ). The $\mathrm{AUC}_{0-\infty}$ for optimized $20 \mathrm{mg}$ 
and $80 \mathrm{mg}$ was found to be $(596.5 \mathrm{ng} \mathrm{h} / \mathrm{ml}, 2647 \mathrm{ng} \mathrm{h} /$ $\mathrm{ml}$ ), marketed $20 \mathrm{mg}$ and $80 \mathrm{mg}(707.5 \mathrm{ng} \mathrm{h} / \mathrm{ml}, 3094$ $\mathrm{ng} \mathrm{h} / \mathrm{ml}$ ). The $\mathrm{AUC}_{\mathrm{t}-\infty}$ for optimized $20 \mathrm{mg}$ and $80 \mathrm{mg}$ was found to be $(85 \mathrm{ng} \mathrm{h} / \mathrm{ml}, 359 \mathrm{ng} \mathrm{h} / \mathrm{ml})$, marketed $20 \mathrm{mg}$ and $80 \mathrm{mg}(106 \mathrm{ng} \mathrm{h} / \mathrm{ml}, 482 \mathrm{ng} \mathrm{h} / \mathrm{ml})$. The $\mathrm{T}_{\max }$ for optimized $20 \mathrm{mg}, 80 \mathrm{mg}$ and marketed $20 \mathrm{mg}, 80 \mathrm{mg}$ tablets was found to be $(3.0 \mathrm{~h})$. The corresponding $\mathrm{t}_{1 / 2}$ for optimized $20 \mathrm{mg}$, $80 \mathrm{mg}$ and marketed $20 \mathrm{mg}$, $80 \mathrm{mg}$ values were found to $3.0 \mathrm{~h}$. Based on results, it was concluded that the above formulation can help in improving the relative bioavailability.

\section{CONCLUSION}

The higher sensitive HPLC method was validated and determined by using Fluvastatin in rabbit plasma. Here the method is fast, rugged, reproducible bio-analytical method. Simple and efficient method was developed and utilized in pharmacokinetic studies to see the investigated analyte in body fluids.

\section{ACKNOWLEDGEMENT}

The authors are grateful to GITAM Institute of Pharmacy, GITAM (Deemed to be University), Visakhapatnam for providing necessary facilities and support.

\section{CONFLICT OF INTEREST}

Authors declare that there was no conflict of interest.

\section{ABBREVIATIONS}

RP-HPLC: Reverse Phase High performance liquid chromatography; NM: Nano Meter; USFDA: United States Food and Drug Administration; USA: United States of America; OPA: Ortho phosphoric acid; CV: Cumulative variation; AUC: Area under the ROC curve; CN: Propyl-Carbo Nitrile Propyl; ISTD: Internal Standard; \%RSD: Relative Standard Deviation; \%CV: Cumulative variation QC: Quality Control.

\section{REFERENCES}

1. Alenghat F, Davis A. Management of Blood Cholesterol. JAMA. 2019;321(8):800.

2. Carmena R, Betteridge D. Diabetogenic Action of Statins: Mechanisms. Current Atherosclerosis Reports. 2019;21(6):23.

3. Lamaida N, Capuano E, Pinto L, Capuano E, Capuano R, Capuano V. The safety of statins in children. Acta Paediatrica. 2013;102(9):857-62.

4. Peters S, Singhateh Y, Mackay D, Huxley R, Woodward M. Total cholesterol as a risk factor for coronary heart disease and stroke in women compared with men: A systematic review and meta-analysis. Atherosclerosis. 2016;248:123-31.
5. Weingartner O, Bohm M, Laufs U. Controversial role of plant sterol esters in the management of hypercholesterolaemia. European Heart Journal. 2008;30(4):404-9.

6. Craeyveld VE, Jacobs F, Gordts CS, DeGeest B. Gene Therapy for Familial Hypercholesterolemia. Current Pharmaceutical Design. 2011;17(24):2575-91.

7. Scorza K, Williams A, Phillips JD, Shaw J. Evaluation of nausea and vomiting. American Family Physician. 2007;76(1):76-84.

8. Singh P, Yoon S, Kuo B. Nausea: A review of pathophysiology and therapeutics. Therapeutic Advances in Gastroenterology. 2015;9(1):98-112.

9. Marx W, Teleni L, McCarthy A, Vitetta L, McKavanagh D, Thomson D, et al. Ginger (Zingiber officinale) and chemotherapy-induced nausea and vomiting: A systematic literature review. Nutrition Reviews. 2013;71(4):245-54.

10. Duncanson K, Burrows T, Walker M, Talley N. Food and Functional Dyspepsia: A Systematic Review. Gastroenterology. 2017;152(5):S303.

11. Jung $\mathrm{H}$, Talley $\mathrm{N}$. Role of the Duodenum in the Pathogenesis of Functional Dyspepsia: A Paradigm Shift. Journal of Neurogastroenterology and Motility. 2018;24(3):345-54.

12. Futagami $\mathrm{S}$, Itoh $\mathrm{T}$, Sakamoto $\mathrm{C}$. Systematic review with meta-analysis: Postinfectious functional dyspepsia. Alimentary Pharmacology and Therapeutics. 2014;41(2):177-88.

13. Straten AV, Cuijpers P. Self-help therapy for insomnia: A meta-analysis. Sleep Medicine Reviews. 2009;13(1):61-71.

14. Qaseem A, Kansagara D, Forciea M, Cooke M, Denberg T. Management of Chronic Insomnia Disorder in Adults: A Clinical Practice Guideline From the American College of Physicians. Annals of Internal Medicine. 2016;165(2):125.

15. Glueck C, Conrad B. Severe vitamin D deficiency, myopathy and rhabdomyolysis. North American Journal of Medical Sciences. 2013;5(8):494.

16. Chavez L, Leon M, Einav S, Varon J. Beyond muscle destruction: A systematic review of rhabdomyolysis for clinical practice. Critical Care. 2016;20(1):135.

17. Bosch X, Poch E, Grau J. Rhabdomyolysis and Acute Kidney Injury. New England Journal of Medicine. 2009;361(1):62-72.

18. Saminathan J, Sankar ASK, Anandakumar K, Srinivasan S. Validated RPHplc Method For Fluvastatin Sodium In Bulk And Its Dosage Form. Journal of Pharmaceutical Sciences and Research. 2009;1(3):90-6.

19. Prakash S, Gopla RP, Sunil KM, Vijay PK, Kiran KV. Analytical method development and Validation for simultaneous estimation of Fluvastatin sodium and Valsartan by RP-HPLC technique. International Journal of Pharmacy and Industrial Research. 2013;03(02):152-7.

20. Fabio PG, Pedro LG, Joao MPA, Anil KS, Erika RMH, Maria IRMS. Development and Validation of Stability Indicating HPLC Methods for Quantitative Determination of Pravastatin, Fluvastatin, Atorvastatin and Rosuvastatin in Pharmaceuticals. Analytical Letters. 2009;42(12):1784-804.

21. Shivani TR, Dilip MG. A Review on Chromatographic and Spectrophotometric method for estimation of Ezetimibe and Fluvastatin. World Journal of Pharmaceutical Research. 2018;7:1014-25.

22. Kalafsky G, Smith HT, Choc MG. High Performance liquid chromatographic method for the determination of Fluvstatin in human plasma. Journal of Chromatography. 1993;614(2):307-13.

23. Ashok HA, Bhanubhai NS, Mahesh GS, Vishnu AS. Development and Validation of Stability indicating RP-HPLC method for estimation of Fluvastatin Sodium in Bulk and Capsule dosage form. Eurasian J Anal Chem. 2017;12(2):87-105.

24. Ashok HA, Umang S, Sagar S, Patel MB. Development and validation of sensitive HPTLC method for quantitative analysis of Fluvastatin sodium in bulk and pharmaceutical dosage form. Journal of Pharmaceutical Research. 2014;6(2):73-8.

25. Tuljapure DS, Gowekar NM, Savita SY. Development and validation of HPTLC method for estimation of Fluvastatin sodium in bulk drug and dosage form. Der Pharmacia Sinica. 2012;3(4):457-61.

26. Prathyusha $\mathrm{PH}$, Anupama B, Jagathi V, Rajesh V. Simultaneous spectrophotometric estimation of Fluvastatin and Fenofibrate in bulk drug and dosage form by using simultaneous equation method. Journal of Pharmaceutical Sciences and Research. 2011;3(2):1042-5.

27. Ashour S, Mahmoud B, Khateeb M. Kinetic spectrophotometric determination of Fluvastatin in pharmaceutical preparations. Int J Biomed Sci. 2010;6(1):19-26. 


\section{PICTORIAL ABSTRACT}

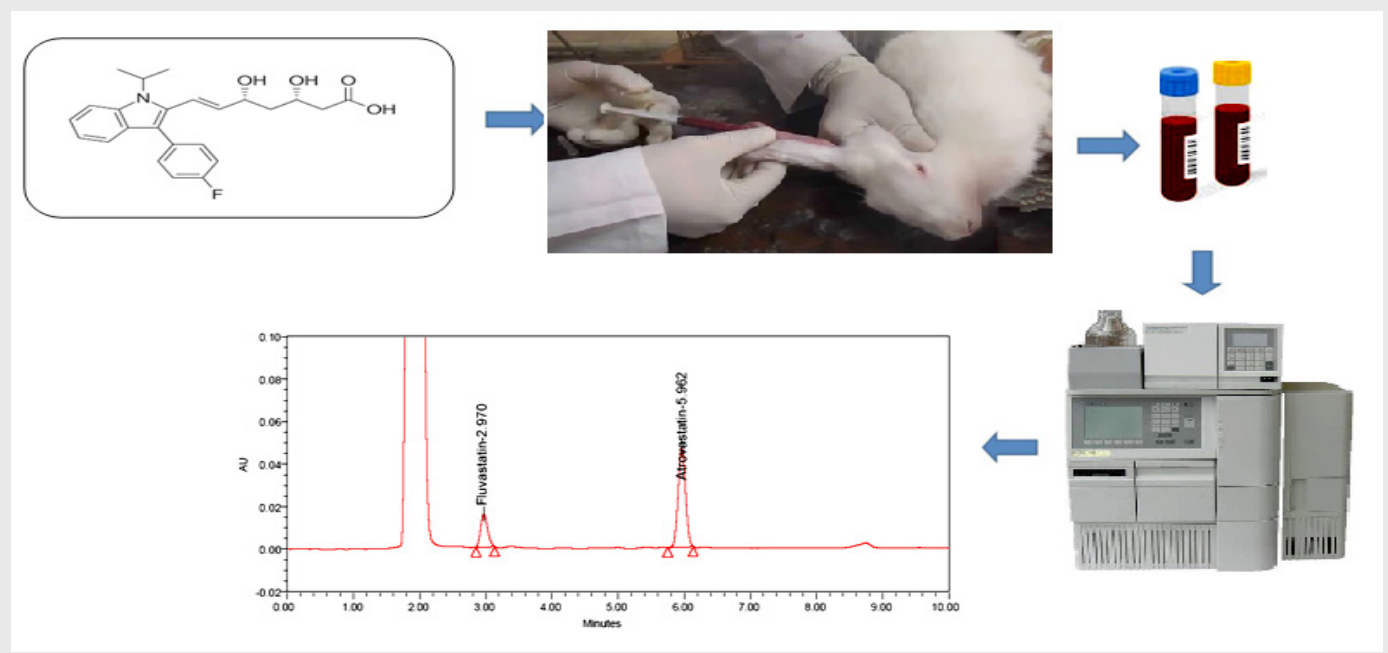

\section{SUMMARY}

The HPLC method describes the analysis of Fluvastatin plasma are very specific and sensitive. The method developed is very simple utilizing liquid-liquid extraction procedure, which makes the method high throughout the analysis. The method shows linearity in concentration range of $5-200 \mathrm{ng} / \mathrm{ml}$. The regression coefficient $\left(R^{2}\right)$ value of the calibration curve is 0.999 . The accuracy data concentrations of $5,50,100$ and $150 \mathrm{ng} /$ $\mathrm{ml}$ showed the percentage recovery of 95.58-100.31\%. The application denotes all system suitability parameters, specificity, linearity and accuracy are in satisfactory correlation with USFDA directives and effectively applied to investigate pharmacokinetic studies with rabbit plasma.

Cite this article: Sandhala D, Lankalapalli S. New Method for the in vivo Estimation of Fluvastatin and its Application for Pharmacokinetic Studies in Rabbit. Indian J of Pharmaceutical Education and Research. 2020;54(4):1153-8. 